\title{
Outbreak of Bovine Herpetic Meningoencephalomyelitis in Southern Brazil
}

\author{
Julia Gabriela Wronski', Bianca Santana Cecco', Luan Cleber Henker', Marina Paula Lorenzett', \\ Paulo Michel Roehe², Fernando Finoketti' ${ }^{2}$, Thaís Moreira Totti ${ }^{2}$ \& Luciana Sonne ${ }^{1}$
}

\begin{abstract}
Background: Herpetic meningoencephalitis is an infectious contagious disease worldwide distributed, most often caused by bovine alphaherpesvirus type 5 (BoHV-5), although bovine alphaherpesvirus type 1 (BoHV-1) may occasionally be the causative agent. The disease is characterized by subacute to acute clinical onset, often affecting animals submitted to stressful situations. Clinical signs are mainly neurologic due to meningoencephalitis and cortical necrosis. The involvement of the spinal cord has also been reported, however in BoHV-1 associated disease only. The aim of this report is to describe an outbreak of bovine meningoencephalomyelitis associated to BoHV-5.

Case: In August 2017, nine 1-year-old calves died in a beef cattle farm with a flock of approximately 400 bovines. The animals presented neurological clinical signs characterized by excessive salivation, nasal and ocular discharges, incoordination, apathy, head tremors, head pressing, wide-based stance, recumbency followed by convulsions and paddling. According to the owner and referring veterinarian, affected animals displayed severe clinical signs with rapid progression and often leading to death in up to seven days. Four of these calves were submitted for necropsy, and gross lesions were present in the brain, characterized by mild to moderate multifocal hemorrhagic and soft areas. On cut surface, extensive areas of dark brown discoloration and malacia were observed. Histologically, lesions were characterized by extensive areas of liquefactive necrosis in the cerebral cortex grey matter, associated with inflammatory infiltrates composed of neutrophils, lymphocytes, plasma cells and foamy macrophages, as well as multifocal to coalescing areas of hemorrhage and fibrin deposition. Intranuclear eosinophilic inclusion bodies were rarely observed in neurons and astrocytes. On leptomeninges, there was diffuse inflammatory infiltrates of lymphocytes and plasma cells. Inflammation was also seen in a milder degree in the spinal cord, characterized by infiltrate of lymphocytes at grey matter, mainly around vessels. A herpesvirus which induced typical cytopathic effect in cell cultures was recovered from tissues. The isolated virus was typed as BoHV-5 by nucleotide sequencing analysis of the $\mathrm{gC}$ coding region.

Discussion: The diagnosis of meningoencephalomyelitis associated to BoHV-5 was based on epidemiological, clinical, macroscopical, histological, virological and genomic findings. In the outbreak here reported, the disease occurred in young animals, with low morbidity but high lethality rates. Clinical signs on this case were consistent with previous reports on the literature. Bovines affected by BoHV-5 may display no gross lesions within the CNS; however, inflammatory and degenerative changes are frequently seen, characterized by malacia, leptomeningeal vessels hyperemia, edema and hemorrhages. Histologically, non-suppurative necrotizing meningoencephalitis is seen, with perivascular inflammatory infiltrates and, occasionally, intranuclear eosinophilic inclusion bodies in astrocytes and neurons. Similar but milder lesions were seen in the spinal cords of two of the necropsied calves, a feature which has only been previously associated to BoHV-1 infections. The identification of the implicated agent was accomplished by virus isolation in cell cultures followed by genome typing. Specific treatments for this condition are not currently available, and the number of animals that recover from clinically apparent disease is extremely low. Preventive measures are based on serological testing of herds, and segregation or elimination of seropositive calves. To avoid progression of the disease in seropositive animals, control efforts must be directed to avoid stressful conditions. Vaccination with BoHV-1 and BoHV-5 vaccines is expected to confer protection to clinical disease.
\end{abstract}

Keywords: bovine alphaherpesvirus 5, neurologic diseases of cattle, viral diseases, neuropathology.

${ }^{1}$ Setor de Patologia Veterinária (SPV), Faculdade de Veterinária (FaVet), Universidade Federal do Rio Grande do Sul (UFRGS), Porto Alegre, RS, Brazil. ${ }^{2}$ Departamento de Microbiologia, Imunologia e Parasitologia, Instituto de Ciências Básicas da Saúde (ICBS), UFRGS, Porto Alegre. CORRESPONDENCE: L. Sonne [lusonne @ yahoo.com.br - Tel.: +55 (51) 3308-6107]. SPV, Faculdade de Veterinária - UFRGS. Avenida Bento Gonçalves n. 9090. Bairro Agronomia. CEP 91540-000 Porto Alegre, RS, Brazil. 


\section{INTRODUCTION}

Herpetic meningoencephalitis is a highly fatal infectious contagious disease caused mainly by bovine alphaherpesvirus type 5 (BoHV-5), a member of the family Herpesviridae, subfamily Alphaherpesvirinae, genus Varicellovirus [11]. Like many herpesvirus infections, BoHV-5 prevalence in a herd may be high; despite that, clinically apparent disease is restricted to a small number of animals, characterized by a subacute to acute clinical onset, usually affecting young or older cattle submitted to stressful situations [11]. The infection is distributed worldwide, particularly in South America, where disease occurs either in small outbreaks or in isolated cases, with animals displaying neurologic manifestations associated to meningoencephalitis and cortical necrosis [5,8]. Involvement of spinal cord has also been reported, although only in cases where bovine alphaherpesvirus type 1 (BoHV-1) has been implicated as the causative agent [1]. In this report, an outbreak of bovine meningoencephalomyelitis associated to BoHV5 infections, occurred at a farm in Southern Brazil.

\section{CASE}

Nine, 1-year-old calves, died in a beef cattle herd in a farm with approximately 400 beef bovines, in August 2017 (2.25\% morbidity and 100\% lethality rates). The farmer reported receiving calves for fattening from different localities (Figure 1-A). Details of clinical history and clinical signs were obtained through inquiries to the owner and the referring veterinarian. History revealed that clinical signs were severe and progressed rapidly, with nearly all affected calves dying in up to seven days. The affected animals presented neurological signs characterized by excessive salivation, nasal and ocular discharges, incoordination, apathy, head tremors, head pressing, wide-based stance, recumbency followed by convulsions and paddling (Figure 1-B). Four of these calves were submitted to necropsy. Gross lesions were present in the brain and were characterized by mild to moderate multifocal hemorrhagic and soft areas at frontal, temporal and parietal lobes (Figure 1-C). On cut surface, extensive areas of dark brown discoloration and malacia were observed (Figure 1-D). Gross lesions were not seen on other organs.

Histologically, lesions were characterized by extensive areas of liquefactive necrosis in the cerebral cortex grey matter (polioencephalomalacia) associated with inflammatory infiltrate composed of neutrophils, lymphocytes, plasma cells and foamy macrophages at the frontal lobe (Gitter cells) and multifocal to coalescing areas of hemorrhage and fibrin deposition (Figure 2-A). Perivascular cuffing (infiltrate of lymphocytes, plasma cells and neutrophils) was detected, as well as edema with prominent endothelial cells on grey and white matters, multifocal gliosis, neuronal ischemic necrosis and satellitosis (Figure 2-B). Intranuclear eosinophilic inclusion bodies were rarely observed in neurons and astrocytes of three out of four cases (Figure 2-C). In addition, in leptomeninges, there was diffuse inflammatory infiltrate of lymphocytes and plasma cells in all four examined calves. Inflammation was also seen in a milder degree in the spinal cord in two necropsiedcalves, characterized by lymphocytic infiltrate in the grey matter, mainly around vessels (perivascular cuffing) [Figure 2-D]. Microscopic examination and severity of all examined bovines is listed on Table 1.

Virus isolation from samples of frontal cortex, cerebellum and spinal cord was carried out as previously described [12]. After three days of cultures' incubation, a cytopathic effect suggestive of herpesvirus infection was identified. (Figure 3-A). The presence of viral DNA in tissues by a differential, type discriminatory polymerase chain reaction (PCR), was performed as previously described [2]. In such samples, BoHV-5 genomes were identified, whereas no BoHV-1 genomes could not be detected (Figure 3-B and C).

\section{DISCUSSION}

The diagnosis of meningoencephalomyelitis due to bovine alphaherpesvirus type 5 was based on epidemiologic, clinical, macroscopic, histologic, microbiologic and molecular findings. The disease occurs mostly in young animals, with low morbidity but high lethality rates $[7,8,11,15]$, although older animals may occasionally be affected [3]. Differential diagnosis to herpetic meningoencephalomyelitis include rabies, hepatic encephalopathy, cerebral babesiosis, malignant catarrhal fever and polioencephalomalacia $[4,11]$.

The main epidemiologic factors for viral spreading on herds include high density, introduction of animals from different properties and management practices which induce stress and, subsequently, immunosuppression, as vaccinations, changes on feeding, castration, weaning, and others [7,8,11]. Additionally, 
Table 1. Histologic lesions and severity presented on each evaluated animal.

\begin{tabular}{ccccc}
\hline Histologic lesion & Bovine 1 & Bovine 2 & Bovine 3 & Bovine 4 \\
\hline $\begin{array}{c}\text { Liquefactive necrosis and inflammatory } \\
\text { infiltrate (neutrophils, lymphocytes, plasma } \\
\text { cells and macrophages) }\end{array}$ & Severe & Moderate & Mild & Moderate \\
Hemorrhage and fibrin deposition & Moderate & Mild & Mild & Moderate \\
Perivascular cuffing & Severe & Moderate & Moderate & Moderate \\
Intranuclear inclusion bodies & Mild & Mild & Absent & Mild \\
Gliosis & Mild & Mild & Mild & Mild \\
Meningitis & Moderate & Moderate & Mild & Mild \\
Myelitis & Absent & Mild & Moderate & Absent \\
\hline
\end{tabular}
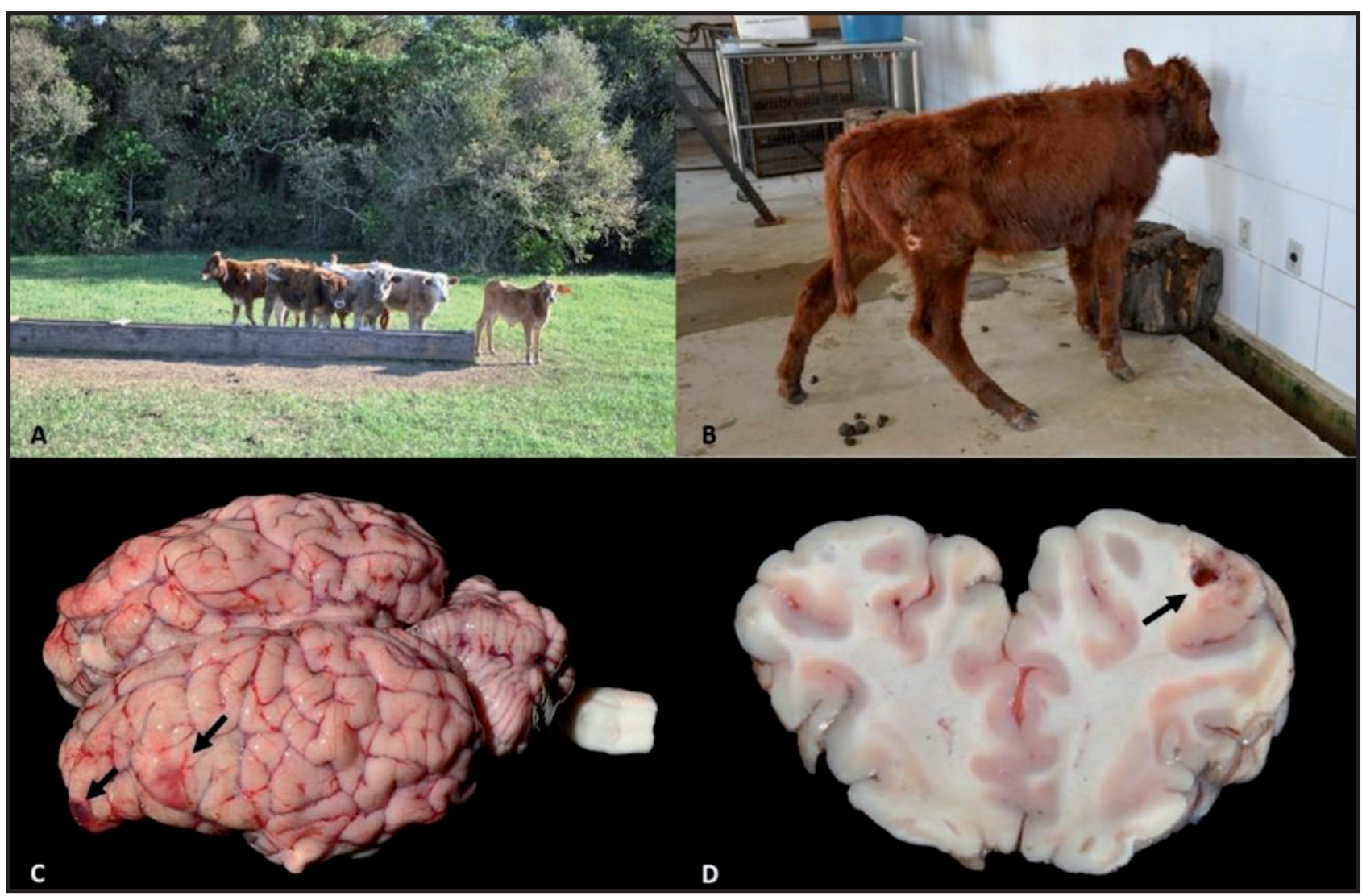

Figure 1. Meningoencephalomyelitis in calves. A- Calves after weaning with different origins and sharing the same feed trough. B- Neurological manifestation of depression and head pressing. C- Multifocal areas of hemorrhage (arrows) on frontal lobe and mild leptomeningeal vessels congestion. D- Transversal section of cerebral cortex, showing brown discoloration with gelatinous consistency (arrow).

in Brazil, herpesvirus infections tend to be highly prevalent, and because of the viral characteristics, diseased animals often represent a minor fraction in relation to the total number of infected animals [2]. Although in this case, according to the owner, the animals were not submitted to handling practices which could lead to acute stress, the calves were from different places and brought to the farm for fattening, being put all in the same lot with high density, in addition to being weaned recently.
Viral transmission occurs by direct or indirect contact between animals, and initial replication occurs on oral, nasal, oropharyngeal and ocular mucosa. Once in the mucosa, viral replication occurs on epithelial cells, with local and systemic viremia and invasion of nerve endings. The virus access central nervous system (CNS) via axonal retrograde transport through cranial nerves, mainly olfactory and trigeminal nerves, reaching CNS five to seven days post infection. At 


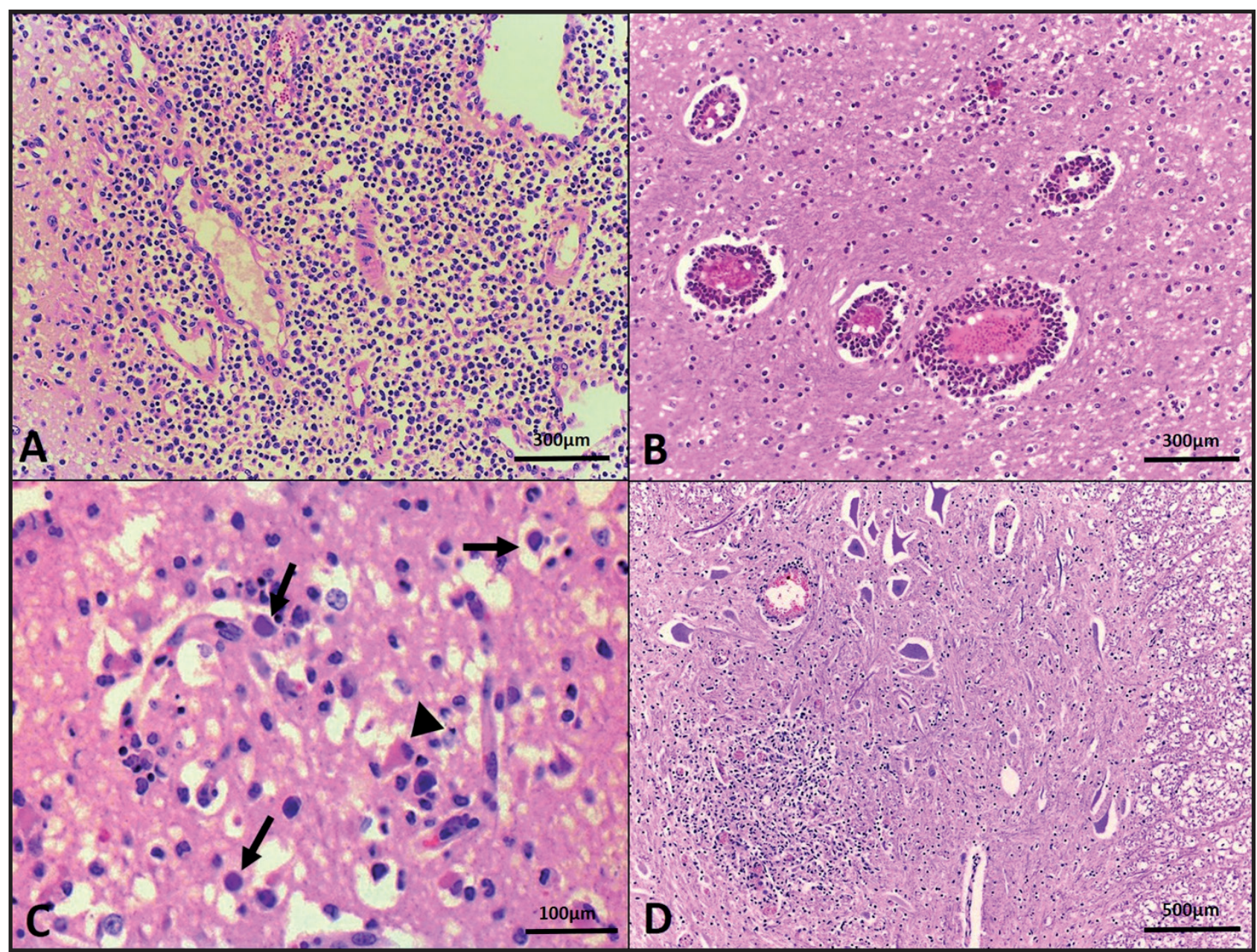

Figure 2. Histologic sections of meningoencephalomyelitis in calves. A- Extensive area of liquefactive necrosis of grey matter of the cerebral cortex associated with inflammatory infiltrate composed of neutrophils, lymphocytes, plasma cells and foamy macrophages [Bar $=300 \mu \mathrm{m}]$. B- Perivascular inflammatory infiltrate composed of lymphocytes, plasma cells and neutrophils, mild evidenciation of endothelial cells and mild perivascular and perineuronal edema [Bar= $300 \mu \mathrm{m}]$. C- Intranuclear basophilic inclusion bodies (arrow) and perineuronal edema, as well as neuronal satelitosis (arrow head) [Bar= $100 \mu \mathrm{m}$ ]. D- Inflammatory infiltrate composed of lymphocytes and plasma cells on spinal cord [Bar= $500 \mu \mathrm{m}]$

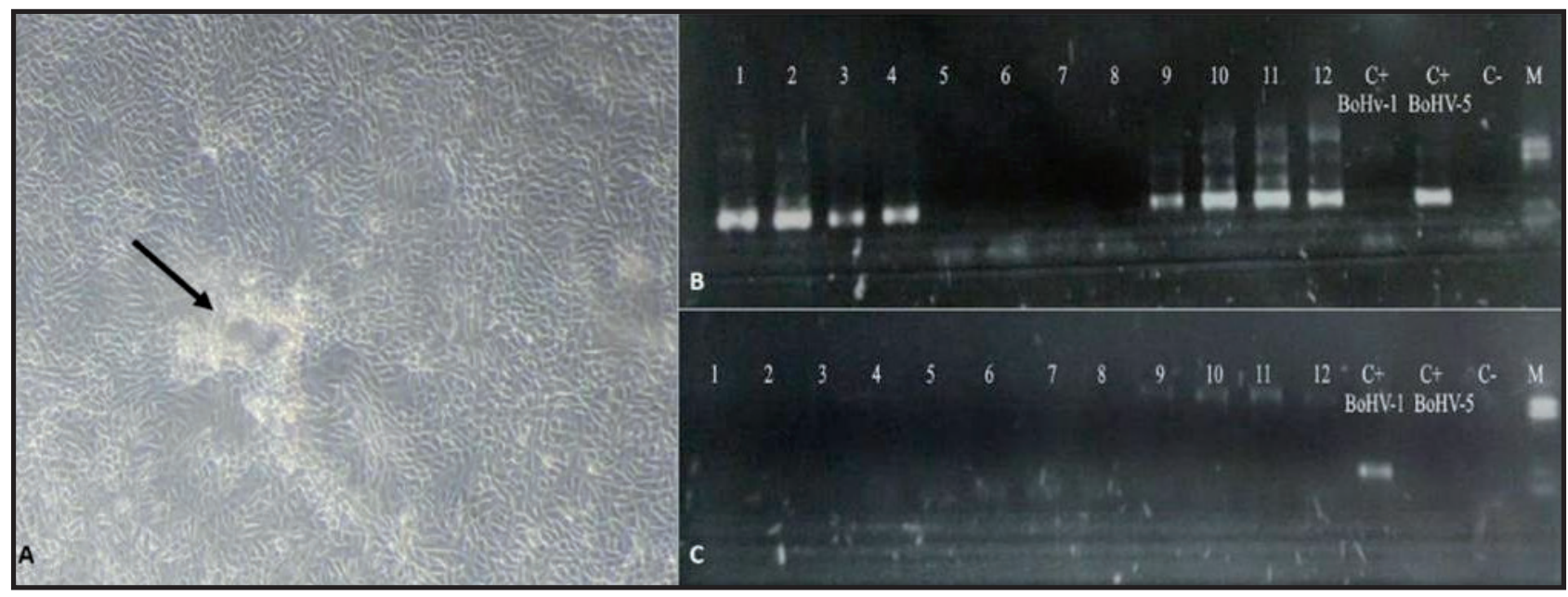

Figure 3. Meningoencephalomyelitis in calves. A- CRIB cells inoculum of the samples, showing mild cellular vacuolization and cytopathic effect, characteristic of Herpesvirus. B- Positive sample for BoHV-5, showing band marking of 1 to 4 and 9 to 12. C- Negative samples for BoHV-1, with no band marking on any of the samples. 
CNS, the agent can actively replicate, causing fatal meningoencephalitis (the main disease manifestation), or it can establish latency in sensory ganglia [11,15].

The clinical onset on this case started with incoordination, depression, ocular and nasal serous discharge, fever, wide based stance, head tremors, head press, weight loss, teeth grinding, progressing to recumbency, convulsions and death, in agreement with previous descriptions in the literature $[7,8,11,15]$. The incubation period may last 7 to 10 days, with a clinical course varying between 1 to 15 days, with an almost invariably fatal outcome $[11,15]$, as in this case, where all calves with clinical signs died in up to 7 days.

Bovines affected with BoHV-5 meningoencephalitis may present no evident gross lesions on CNS; however, inflammatory and degenerative changes are frequently seen with a broad variation on the degree of CNS involvement [11]. In the case here reported, necropsied calves presented lesions at encephalic rostral portions characterized by leptomeningeal vessels hyperemia, edema and hemorrhagic areas on cut surface, as well as softening and yellowish areas on frontal lobes, features of malacia, as previously described $[7,8]$. With the disease evolution, these areas became soft, grayish and gelatinous, and may leave a cavity between white matter and leptomeninges (residual lesion) [7,8,11]. However, these lesions were not seen in the animals examined in the present outbreak.

Histologically, non-suppurative necrotizing meningoencephalitis is seen, varying according to the location and severity on each case [11]. Perivascular inflammatory infiltrate composed mostly of lymphocytes and plasma cells on neuropil and meninges, neutrophils on neuropil, neuronal necrosis and satellitosis and varying amount of gitter cells are observed $[5,7,8,11]$. Occasionally, there are intranuclear eosinophilic inclusion bodies in astrocytes and neurons, which are extremely suggestive of the disease but cannot be observed in all cases $[5,7,8,11]$. In the calves examined in the present study, there was variation on degree of severity for inflammatory and degenerative changes, and inclusion bodies were seen in three out of four cases. Additionally, similar though milder lesions were seen at spinal cord on two of the necropsied calves, a feature previously described only for BoHV-1 meningoencephalitis [1].

Diagnostic of herpetic meningoencephalomyelitis can be presumptive, based on epidemiologic, clinical, gross and histologic findings $[4,8,11]$. However, due to genetic and antigenic similarity of BoHV-5 with bovine alphaherpesvirus type 1 (BoHV-1), agent of bovine infectious rhinotracheitis which can occasionally cause neurologic disease $[8,13]$, it is necessary to confirm the identity of the agent, which in this case was done by virus isolation followed by typing with a discriminative PCR [2]. No BoHV-1 or other herpesviruses were recovered from any of the samples examined.

Specific treatments for this condition are not reported on literature, and the number of animals who recover of clinically apparent disease is extremely low, feature also observed on this case. Preventive measures are based on serological testing of herds, and segregation or elimination of seropositive calves. However, seroprevalence of BoHV-5 infections may be high in Brazilian herds [2]. To avoid progression of the disease in seropositive animals, control efforts must be directed to avoid stressful conditions. [4,7,8,11]. Previous studies provide evidence that animals immunized to BoHV-1 may be, at least partially, protected to BoHV-5 clinical disease. Some vaccines containing specific BoHV-5 antigen are already available commercially and may reduce the occurrence of meningoencephalitis. Thus, vaccination with BoHV-1 and BoHV-5vaccines can be used in attempting to reduce clinically apparent BoHV-5 associated disease, although vaccines are not capable of avoiding infection with wild type virus [11].

This case reports an outbreak of herpetic meningoencephalomyelitis due to BoHV-5 with low morbidity and high lethality rates, agreeing with the literature. Additionally, it was observed inflammatory lesions in the spinal cord, which was only described for BoHV-1. This demonstrates the importance of evaluating the entire central nervous system.

Acknowledgements. PMR is CNPq 1A research fellows. Financial support: FINEP, CNPq, FAPERGS.

Declaration of interest. The authors report no conflicts of interest. The authors alone are responsible for the contents and writing of the paper. 


\section{REFERENCES}

1 Beck B.E. 1975. Infectious bovine rhinotracheitis encephalomyelitis in cattle and its differential diagnosis. Canadian Veterinary Journal. 16(9): 269-271.

2 Campos F.S., Franco A.C., Hübner S.O., Oliveira M.T., Silva A.D., Esteves P.A., Roehe P.M. \& Rijsewijk F.A.M. 2009. High prevalence of co-infections with bovine herpesvirus 1 and 5 found in cattle in southern Brazil. Veterinary Microbiology. 139(1-2): 67-73.

3 Colodel E.M., Nakazato L., Weiblen R., Mello R.M., Silva R.R.P., Souza M.A., Oliveira-Filho J.A. \& Caron L. 2002. Meningoencefalite necrosante em bovinos causada por herpesvírus bovino no estado de Mato Grosso, Brasil. Ciência Rural. 32(2): 293-298.

4 Halfen D.C. \& Riet-Correa F. 2007. Infecções Por Herpesvírus Bovino-1 e Herpesvirus Bovino-5. In: Riet-Correa F., Schild A.L., Lemos E.A.A. \& Borges J.R. (Eds). Doenças De Ruminantes e Equídeos. v.1. 3.ed. São Paulo: Livraria Varela, pp.126-137.

5 Perez S.E., Bretschneider G., Leunda M.R., Osorio F.A., Flores E.F. \& Odeón A.C. 2003. Primary Infection, Latency, and Reactivation of Bovine Herpesvirus Type 5 in Bovine Nervous System. Veterinary Pathology. 39(4): 437-444.

6 Riet-Correia F. \& Méndez M.D.C. 2007. Intoxicações por Plantas e Micotoxinas. In: Riet-Correa F., Schild A.L., Lemos E.A.A. \& Borges J.R. (Eds). Doenças De Ruminantes e Equídeos. v.2. 3.ed. São Paulo: Livraria Varela, pp.99222.

7 Rissi D.R. \& Barros C.S.L. 2013. Necrotizing Meningoencephalitis in a Cow. Veterinary Pathology. 50(5): 926-929.

8 Rissi D.R., Oliveira F.N., Rech R.R., Pierezan F., Lemos R.A.A. \& Barros C.S.L. 2006. Epidemiologia, sinais clínicos e distribuição das lesões encefálicas em bovinos afetados por meningoencefalite por herpesvírus bovino-5. Pesquisa Veterinária Brasileira. 26(2): 123-132.

9 Rissi D.R., Pierezan F., Oliveira-Filho J.C., Lucena R.B., Carmo P.M.S. \& Barros C.S.L. 2010. Abordagem diagnóstica das principais doenças do sistema nervoso de ruminantes e equinos no Brasil. Pesquisa Veterinária Brasileira. 30(11): 958-967.

10 Rissi D.R., Pierezan F., Silva M.S., Flores E.F. \& Barros C.S.L. 2008. Neurological disease in cattle in southern Brazil associated with Bovine herpesvirus infection. Journal of Veterinary Diagnostic Investigation. 20: 346-349.

11 Rissi D.R., Rech R.R., Flores E.F., Kommers G.D. \& Barros C.S.L. 2007. Meningoencefalite por herpesvírus bovino-5. Pesquisa Veterinária Brasileira. 27(7): 251-260.

12 Salvador S.C., Lemos R.A.A., Riet-Correa F., Roehe P.M. \& Osório A.L.A.R. 1998. Meningoencefalite em bovinos causada por herpesvírus bovino-5 no Mato Grosso do Sul e São Paulo. Pesquisa Veterinária Brasileira. 8(2): 75-82.

13 Silva M.S., Brum M.C.S., Weiblen R. \& Flores E.F. 2007. Identificação e diferenciação de herpesvírus bovino tipos 1 e 5 isolados de amostras clínicas no Centro-Sul do Brasil, Argentina e Uruguai (1987-2006). Pesquisa Veterinária Brasileira. 27(10): 403-408.

14 Thiry J., Keuser V., Muylkens B., Meurens F., Gogev S., Vanderplasschen A. \& Thiry E. 2006. Ruminant alphaherpesviruses related to bovine herpesvirus 1. Veterinary Research. 37: 169-190.

15 Zajac M.P.D.M., Ladelfa M.F., Kotsias F., Muylkens B., Thiry J., Thiry E. \& Romera S.A. 2010. Biology of bovine herpesvirus 5. The Veterinary Journal. 184: 138-145. 